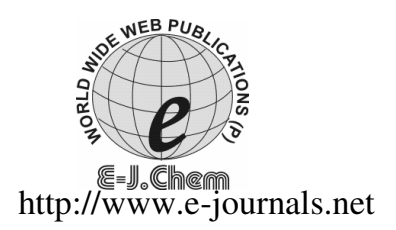

ISSN: 0973-4945; CODEN ECJHAO

E-Journal of Chemistry

2011, 8(4), 1546-1555

\title{
Evaluation of Physicochemical Characteristics of Various River Water in India
}

\author{
SULEKH CHANDRA*, ARENDRA SINGH, \\ PRAVEEN KUMAR TOMAR and ADARSH KUMAR. \\ Department of Chemistry, Zakir Husain College (University of Delhi) \\ J.L.Nehru marg, New Delhi-110002, India \\ schandra_00@yahoo.com
}

Received 18 October 2010; Accepted 17 December 2010

\begin{abstract}
Physicochemical parameters of water samples collected from various rivers in India. Water samples under investigations were collected from Krishana Vijaywada, Gomti Lucknow, Hoogali Kolkata, Ganga Kasi, Mahanadi Katak, Cauveri river Tiruchirapalli station during (July - August) seasons in the year 2009. The different sites show significant enrichment with $\mathrm{Zn}, \mathrm{Fe}, \mathrm{Ni}, \mathrm{Cr}, \mathrm{Ca}$ and $\mathrm{Mg}$ indicating input from industrial sources. The observed values of different physicochemical characteristics like $\mathrm{pH}$, temperature, turbidity, total hardness (TH), iron, chloride, total dissolved solids(TDS), $\mathrm{Ca}^{2+}, \mathrm{Mg}^{2+}, \mathrm{SO}_{4}{ }^{2-}, \mathrm{F}$ total alkalinity (TA), $\mathrm{COD}, \mathrm{BOD}$, phosphate, FRC (Free residual chlorine), total silica and hydrazine of samples were compared with standard values recommended by Bureau of Indian standard (BIS).
\end{abstract}

Keywords: River pollution, Water Quality, Physicochemical characteristics, COD, BOD

\section{Introduction}

India is rich in water resources, being endowed with a network of rivers and blessed with snow cover in the Himalayan range that can meet a variety of water requirements of the country. However, with the rapid increase in the population of the country and the need to meet the increasing demands of irrigation, human and industrial consumption, the available water resources in many parts of the country are getting depleted and the water quality has deteriorated. Indian rivers are polluted due to the discharge of untreated sewage and industrial effluents. The growing problem of degradation of our river ecosystem has necessitated the monitoring of water quality of various rivers all over the country to evaluate their production capacity, utility potential and to plan restorative measures ${ }^{1-2}$. Most municipal plants are not designed to treat toxic pollutants found in industrial wastewater ${ }^{3}$. It can be said that no water is pure or clean owing to the presence of some quantities of gases, 
minerals and life. However, for all practical purposes, pure water is considered to be that which has low dissolved or suspended solids and obnoxious gases as well as low in biological life. Such high quality of water may be required only for drinking purposes while for other uses like agriculture and industry, the quality of water can be quite flexible and water polluted up to certain extent in general sense can be regarded as pure ${ }^{4}$. Industrial waste water is a major problem in the global context for pollution. It has been suggested that it is the leading worldwide cause of deaths ${ }^{5}$ and diseases and that it accounts for the deaths of more than 14,000 people daily ${ }^{6}$. Presently water samples are being analyzed for certain parameters given in Table $1 \& 2$ consisting of physicochemical parameters for ambient water samples apart from the field observations. A good numbers of river water analysis experiment are regularly conducted by different groups of chemists and biologists across the country ${ }^{7-10}$.

\section{Experimental}

Water samples under investigations were collected from Krishana Vijaywada, Gomuti Lucknow, Hoogali Kolkata, Ganga Kasi, Mahanadi Katak, Cauveri river Tiruchirapalli station during (July-August) seasons in the year 2009. During the sampling period overall climatic condition was a little cloudy followed by minor rainfall at some locations. Grab samples of water were collected in high grade poly propylene bottles in triplicate and mixed to get a composite sample for each site. All the sample bottles were stored in iceboxes till brought to the laboratory for analysis. Six samples were taken from each site, which were homogenized and the composite samples were stored in high grade poly propylene bottles. Solutions used for the studies were prepared from analytical grade chemicals, in double distilled water or in high purity organic solvents. Water samples were taken in high grade plastic bottle. Sampling was carried one time, during (July-August) season 2009. Water analysis was carried out by following standard methods ${ }^{11-13}$. The temperature was measured using a mercury filled centigrade thermometer on site. Dissolved oxygen is trapped on the site Wrinkler method. Total hardness, $\mathrm{Ca}^{++}$and $\mathrm{Mg}^{++}$determined by EDTA complexometric titration using EBT and patton redder as indicator, $\mathrm{Cl}$ - was also determined by titration method. Physical parameter i.e. $\mathrm{pH}$ was determined by digital $\mathrm{pH}$ meter (Thermo Orion), electrode which was calibrated as per instructional manual. The conductivity and total dissolve solid was determined by the conductivity meter (Mettler Toledo MC-226 conductivity meter). Turbidity and colour determined by Merck spectrophotometer (Spectroquant NOVA-60), temperature is determined by mercury filled centigrade thermo meter (Zeal thermo meter) fluoride determined by digital meter (Thermo Orion), electrode which was calibrated as per instructional manual. The heavy metals determined by using Spectrophotometer (Thermo electron corporation). BOD determined by the TS-606 (Merck). COD determined by the spectroquant TR-302.

\section{Results and Discussion}

\section{Temperature}

The temperature of all samples was determined at the time of sampling on site. The temperature of river water ranging from $26-31{ }^{\circ} \mathrm{C}$. The all values of temperature are given in Table 1 and Figure 1.

\section{Turbidity}

Turbidity is a measurement of the cloudiness of water. It is measured by passing a beam of light through the water and measuring photometrically the light scattered at right angles to the beam. Result is expressed in nephelometric turbidity units (NTU). Water cloudiness is 
caused by material suspended in water. In the present study the water from Hoogali Kolkata and Krishna Vijaywada have good turbidity (1 and 2 NTU), clear and colorless sample while other samples like Gomati Lucknow, Ganga Kashi, Maha Nadi Katak and Cauvery river Tiruchirapalli hazy color and high turbidity $(8,4,5$ and 3 NTU) shown in Figure 2.

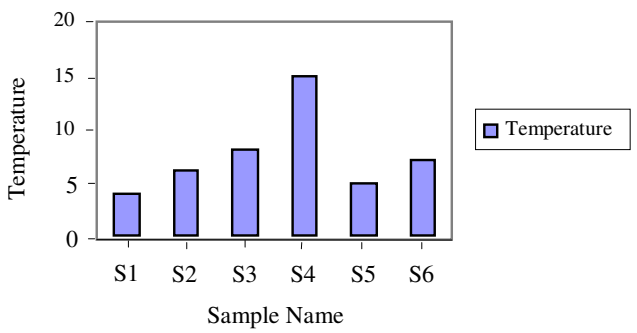

Figure 1. Temperature in various sample

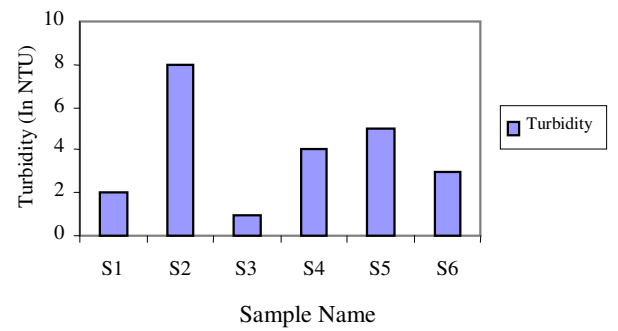

Figure 2. Turbidity in various sample $p H$

The observed $\mathrm{pH}$ value ranging from 6.78 to 7.87 show that the present water samples are slightly alkaline in Ganga Kasi and slightly acidic in Hoogaly Kolkata. The $\mathrm{pH}$ value of all rivers found under limit desirable IS: 10500-1991 (Beuro of Indian Standard) and maximum permissible limit prescribed by WHO. The results obtained from analysis of water samples of rivers are shown in Table1 and Figure 3.

Table 1. Physicochemical characteristics of water of rivers Krishna Vijaywada (S1) Gomati Lucknow (S2) Hoogali Kolkata (S3) Ganga Kasi (S4) MahaNadi Katak (S5) and Cauveri river (S6) in India.

\begin{tabular}{ccccccccc}
\hline S. No & Parameters & $\begin{array}{c}\text { Specification } \\
\text { as per I.S. }\end{array}$ & S1 & S2 & S3 & S4 & S5 & S6 \\
\hline 1 & Temperature & $-{ }^{\circ}$ C & 31.0 & 26.0 & 28.1 & 27.6 & 28.3 & 29.1 \\
2 & Colour & $5-25 \mathrm{Hazen}$ & 4 & 6 & 8 & 15 & 5 & 7 \\
3 & Turbidity & $5-10 \mathrm{NTU}$ & 3 & 2 & 1 & 7 & 2 & 3 \\
4 & $\mathrm{pH}$ & $6.5-8.5$ & 7.06 & 7.01 & 6.78 & 7.87 & 7.11 & 7.02 \\
5 & $\mathrm{EC}$ & & 581 & 215 & 262 & 222 & 133 & 98.6 \\
6 & Alkalinity & $200-600 \mathrm{mg} / \mathrm{L}$ & 28 & 23 & 18 & 23 & 66 & 51 \\
7 & Fluoride & $1-1.5 \mathrm{mg} / \mathrm{L}$ & 0.43 & 0.12 & 0.19 & 0.068 & 0.13 & 0.15 \\
8 & Chloride & $250-1000 \mathrm{mg} / \mathrm{L}$ & 58 & 8 & 21 & 31 & 12 & 15 \\
9 & Sulphate & $200-400 \mathrm{mg} / \mathrm{L}$ & 57 & 25 & 2 & 57 & 2 & 3 \\
10 & Phosphate & & 0.01 & 0.12 & 0.14 & 0.06 & 0.05 & 0.05 \\
11 & T H & $300-600 \mathrm{mg} / \mathrm{L}$ & 360 & 300 & 440 & 96 & 68 & 40 \\
12 & Ca H & $75-200 \mathrm{mg} / \mathrm{mL}$ & 141 & 124 & 171 & 35.2 & 28.2 & 18.1 \\
13 & Mg H & & 219 & 176 & 269 & 61.1 & 39.8 & 21.9 \\
14 & TDS & $500-2000 \mathrm{mg} / \mathrm{L}$ & 291 & 106 & 131 & 112 & 68.2 & 48.8 \\
15 & Silica & & 0.26 & 3.39 & 2.5 & 3.94 & 1.01 & 1.16 \\
16 & SO ${ }^{-}$ & & 0.70 & 1.4 & 0.5 & 4.4 & 0.1 & 0.3 \\
17 & Hydrazine & & ND & 0.018 & 0.005 & 0.002 & ND & 0.001 \\
18 & COD & & 58 & 14 & 25 & 22 & 6 & 8 \\
19 & BOD & & 7.2 & 2.1 & 5.5 & 3.9 & 1.6 & 2.2 \\
20 & FRC & $0.2 \mathrm{mg} / \mathrm{L}$ & ND & 0.1 & ND & 0.12 & ND & ND \\
\hline
\end{tabular}

$E C=$ Electrical conductivity (micro simian), TH=Total hardness, CaH=Calcium hardness, $C O D=$ Chemical oxygen demand, BOD=Biological oxygen demand and TDS=Total dissolve solid, $N D=$ Not detected, $F R C=$ Free residual Chlorine, $S M C L=$ Secondary Maximum Contamination Limit 


\section{Total dissolved salts (TDS)}

Total dissolved solids levels less than $500 \mathrm{mg} / \mathrm{L}$ are considered to be good. Total dissolved solids indicate the amount of chemical substances dissolved in the water. At increasing levels, palatability decreases. Levels in excess of $1000 \mathrm{mg} / \mathrm{L}$ may produce a bad taste. Water used for irrigation can vary greatly in quality depending upon type and quantity of dissolved salts. Salts are present in irrigation water in relatively small but significant amounts. They originate from dissolution or weathering of the rocks and soil, including dissolution of lime, gypsum and other slowly dissolved soil minerals. These salts are carried with the water to wherever it is used. In the case of irrigation, the salts are applied with the water and remain behind in the soil as water evaporates or is used by the crop. A salinity problem exists if salt accumulates in the crop root zone to a concentration that causes a loss in yield. Yield reductions occur when the salts accumulate in the root zone to such an extent that the crop is no longer able to extract sufficient water from the salty soil solution, resulting in a water stress for a significant period of time. If water uptake is appreciably reduced, the plant slows its rate of growth. Water with TDS less than $450 \mathrm{mg} / \mathrm{L}$ is considered good and that with greater than $2000 \mathrm{mg} / \mathrm{L}$ is unsuitable for irrigation purpose. In the present study the minimum value of total dissolved solids was found in a range of $48.8 \mathrm{mg} / \mathrm{L}$ to $291 \mathrm{mg} / \mathrm{L}$. The maximum value was found in Krishana Vijaywada $291 \mathrm{mg} / \mathrm{L}$ and minimum value of TDS found in Cauveri river Tiruchirapalli $48.8 \mathrm{mg} / \mathrm{L}$. Other values are shown in Table 1and Figure 4.

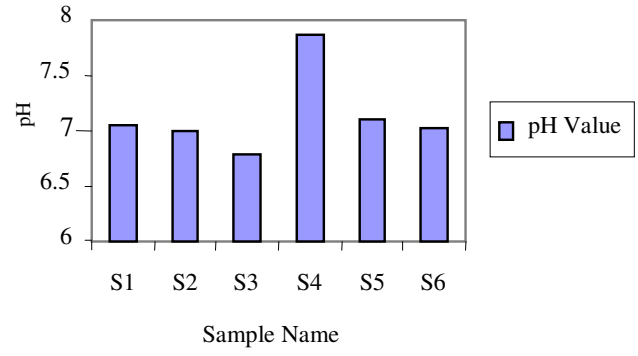

Figure 3. $\mathrm{pH}$ value of various sample

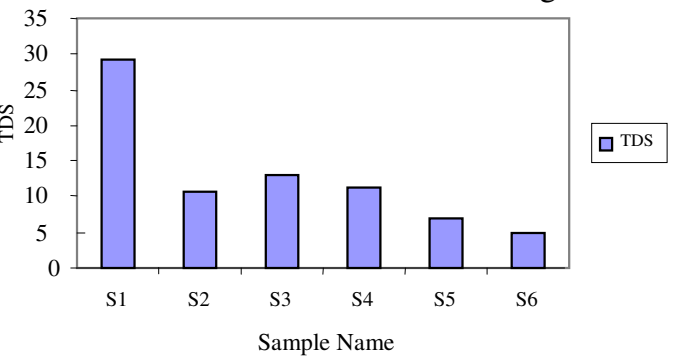

Figure 4. TDS value of various sample

\section{Electrical conductivity (EC)}

The most influential water quality guideline on crop productivity is the water salinity hazard as measured by electrical conductivity (EC) ${ }^{14}$. The primary effect of high EC water on crop productivity is the inability of the plant to compete with ions in the soil solution for water (physiological drought). The higher the EC, the less water is available to plants, even though the soil may appear wet. Because plants can only transpire "pure" water, usable plant water in the soil solution decreases dramatically as EC increases. Water with EC less than $98.6 \mu \mathrm{s} / \mathrm{cm}$ is considered good and that with greater than $581 \mu \mathrm{s} / \mathrm{cm}$ is unsuitable for irrigation. In our 2009 river study, the minimum EC was recorded in $98.6 \mu \mathrm{s} / \mathrm{cm}$ in Cauveri river Tiruchirapalli. The maximum EC was recorded in 581 in Krishana Vijaywada. Other EC was 133, 215, 222 and $222 \mu \mathrm{s} / \mathrm{cm}$ in Maha Nadi Katak, Gomati Lucknow and Gaga Kasi respectively (Figure 5).

\section{Fluorides}

The recommended limit is $1.5 \mathrm{mg} / \mathrm{L}$. Values over $1.5 \mathrm{mg} / \mathrm{L}$ may cause dental fluorosis or mottling of permanent teeth in children between the ages of birth to 13 years. The effect of 
excess fluoride in drinking water on human beings leads to fluorosis. This is a condition of fluoride accumulating in bones. Fluoride can also be harmful for pregnant women and breast feeding women. The disease causes pain in bones, stiffness of back bone etc. Fluorosis can also affect the teeth. It turns teeth to yellow and patches. These may lead to brown horizontal streams on the teeth. The teeth may also affect the whole tooth, get pitted perforated and ultimately chipped off. Apart from these two major effects of fluorosis, other ailments are also reported viz, neurological, muscular allergic manifestations. It may also say to cause gastro intestinal problems ${ }^{15-17}$. In rivers water fluoride concentration found lower concentration $0.068 \mathrm{mg} / \mathrm{L}$ in Ganja Kasi to $0.43 \mathrm{mg} / \mathrm{L}$ Krishana Vijaywada. Other fluoride concentration $0.12 \mathrm{mg} / \mathrm{L}$ in Gomati Lucknow, $0.13 \mathrm{mg} / \mathrm{L}$ in Maha Nadi Katak, $0.15 \mathrm{mg} / \mathrm{L}$ in Cauveri river Tiruchirapalli, $0.19 \mathrm{mg} / \mathrm{L}$ in Hoogali Kolkata. These all value of fluoride concentration in all rivers under study area found desired limit (Figure 6).

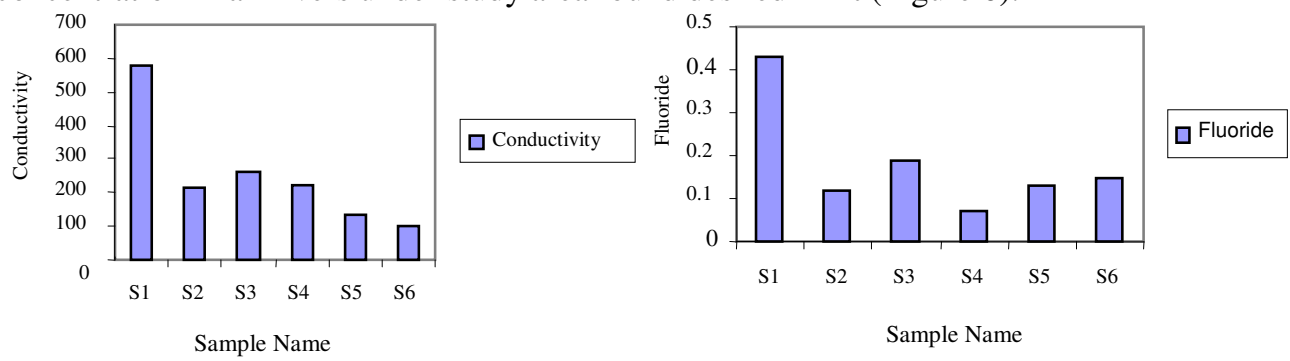

Figure 5. EC value of various sample

Figure 6. Fluoride in various sample

\section{Chloride}

The recommended limit is $250 \mathrm{mg} / \mathrm{L}$. Excessive chlorides give the water a "salty" taste, usually noticeable over $500 \mathrm{mg} / \mathrm{L}$. High chloride concentrations in the water may also be associated with the presence of sodium in drinking water. Elevated concentration levels of sodium may have an adverse health effect on normal healthy persons. In the present study the concentration of chloride was less in Gomati Lucknow i.e. $8 \mathrm{mg} / \mathrm{L}$ and high concentration in Krishana Vijaywada $58 \mathrm{mg} / \mathrm{L}$. However water from Hoogali Kolkata Ganga Kasi, Maha Nadi Katak and Cauveri river Tiruchirapalli samples chloride contains 21, 31, 12 and $15 \mathrm{mg} / \mathrm{L}$ respectively shown in Figure 7.

\section{Sulphate}

The recommended maximum concentration is $500 \mathrm{mg} / \mathrm{L}$. Excess sulphate levels may have a laxative effect on new users and produce an objectionable taste. Regular users tend to become accustomed to high sulphate levels. High concentrations of sulphate in drinking water have three effects: (1) water containing appreciable amounts of sulphate $\left(\mathrm{SO}_{4}{ }^{-2}\right)$ tends to form hard scales in boilers and heat exchangers; (2) sulphate cause taste effects and (3) sulphate can cause laxative effects with excessive intake. The laxative effect of sulphate is usually noted in transient users of a water supply because people who are accustomed to high sulphate levels in drinking water have no adverse response. Diarrhea can be induced at sulphate levels greater than $500 \mathrm{mg} / \mathrm{L}$ but typically near 750 $\mathrm{mg} / \mathrm{L}$. While sulphate imparts a slightly milder taste to drinking water than chloride, no significant taste effects are detected below $300 \mathrm{mg} / \mathrm{L}$. Sulphate cannot readily be removed from drinking water, except by expensive process such as distillation, reverse osmosis, or electrodialysis. In the present study the low concentration was found in each sample as shown in Table 1 and Figure 8. 


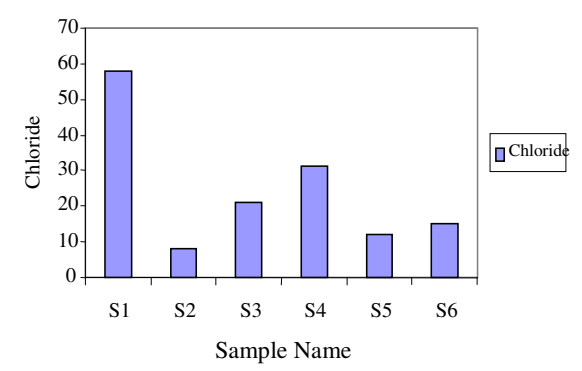

Figure 7. Chloride in various sample

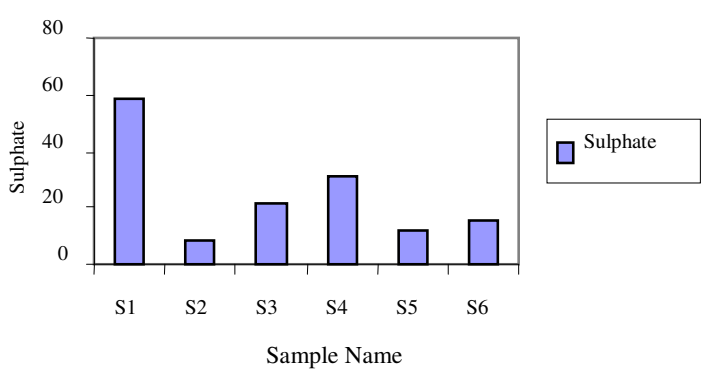

Figure 8. Sulphate in various sample

\section{Magnesium}

Magnesium ${ }^{18}$ content of water is considered as one of the most important qualitative criteria in determining quality of water for irrigation. Magnesium content is calculated by the following formula.

$$
\text { Magnesium content }=\left[\mathrm{Mg}^{2+} /\left(\mathrm{Mg}^{2+}+\mathrm{Ca}^{2+}\right)\right] 100
$$

Magnesium content of water is considered as one of the most important qualitative criteria in determining the quality of water for irrigation. Generally, calcium and magnesium maintain a state of equilibrium in most waters. More magnesium in water will adversely affect crop yields as the soils become more alkaline. In the present study, the magnesium content of the water of Hoogali Kolkata found highest values $269 \mathrm{mg} / \mathrm{L}$ and lowest values is found in Cauvery river Tiruchirapalli $21.9 \mathrm{mg} / \mathrm{L}$. the water in all river found is suitable for irrigation purpose in terms of magnesium content, other value of magnesium is shown in Table 1 and Figure 9.

\section{Biochemical oxygen demand}

The biochemical oxygen demand, abbreviated as BOD, is a test for measuring the amount of biodegradable organic material present in a sample of water. The result is expressed in terms of $\mathrm{mg} / \mathrm{L}$ of BOD which microorganisms, principally bacteria will consume while degrading these materials. As the measurement of BOD takes too long time $\left(20\right.$ days at $\left.20{ }^{\circ} \mathrm{C}\right)$, the determination of BOD after 5 days incubation is preferred (BOD) and the values of BOD being nearly $65 \%$ of the total BOD. The maximum BOD in Krishna Vijaywada $7.2 \mathrm{mg} / \mathrm{L}$ and minimum value of BOD was observed in Maha Nadi Katak $1.6 \mathrm{mg} / \mathrm{L}$, while Gomati Lucknow, Cauvery rive Tiruchirapalli, Ganga Kasi and Hoogali Kolkata BOD value found 2.1, 2.2, 3.9 and $5.5 \mathrm{mg} / \mathrm{L}$ respectively (Figure 10).

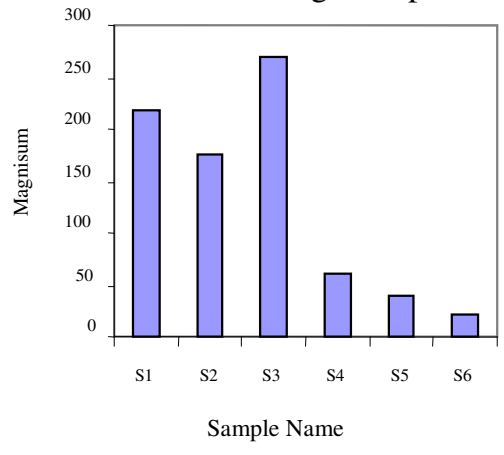

Figure 9. Magnisium

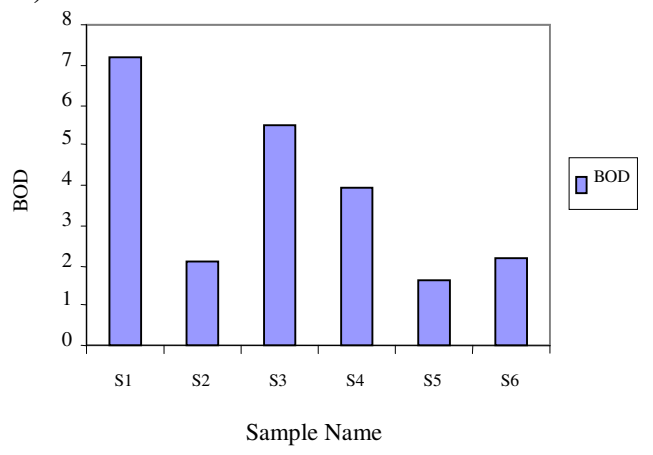

Figure 10. BOD in various sample 


\section{Chemical oxygen demand}

Chemical oxygen demand is a rapid $(2 \mathrm{~h})$ test which measure the oxygen required for the oxidation of all the substance present in water, included those one not biologically decomposable. In the present study COD value of the MahaNadi Katak3.5 mg/L and Krishna Vijaywada $58 \mathrm{mg} / \mathrm{L}$ while Cauvery river Tiruchirapalli, Gomati Lucknow, Ganga Kasi and Hoogali Kolkata value found 4.6, 14.0, 22.0 and 25.0 mg/L respectively (Figure 11).

\section{Alkalinity}

The maximum permissible limit of alkalinity is $200-600 \mathrm{mg} / \mathrm{L}$, high levels can also give a 'flat' taste to the water and cause "itchy" skin when bathing. In the present study, maximum alkalinity found in $66 \mathrm{mg} / \mathrm{L}$ in Maha Nadi Katak and lowiest alkalinity in Hoogali Kolkata $18 \mathrm{mg} / \mathrm{L}$, others river water Krishana Vijaywada, Gomati Lucknow, Ganga Kasi and Cauvery River 28, 23, 23 and $51 \mathrm{mg} / \mathrm{L}$ respectively (Figure 12).

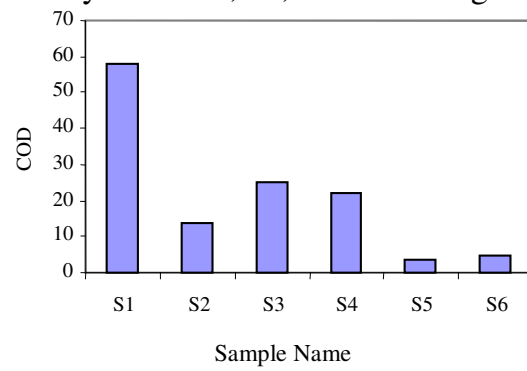

Figure 11. COD in various sample

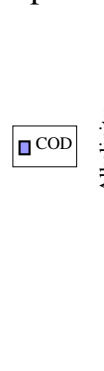

Figure 12. Alkalinity value of various sample

\section{Silica}

Silica (silicon dioxide) is a compound of silicon and oxygen $\left(\mathrm{SiO}_{2}\right)$. It is a hard, glassy mineral substance which occurs in a verity of such as sand, quartz, sandstone and granite. In the present study silica of the Krishna Vijaywada, Gomati Lucknow, Hoogali Kolkata, Ganga Kasi, Maha Nadi Katak and Cauvery river Tiruchirapalli value found 0.26, 3.39, 2.50, 3.94, 1.01 and $1.16 \mathrm{mg} / \mathrm{L}$ respectively (Figure 13 ).

\section{FRC}

Free chlorine is defined as the concentration of chlorine $\left(\mathrm{Cl}_{2}\right)$, hypochlorous acid $(\mathrm{HOCl})$ and /or hypochlorite ion $\left(\mathrm{OCl}^{-}\right)$. In the present study free residual chlorine all river water samples was detected only in two sample Gomati Lucknow $0.01 \mathrm{mg} / \mathrm{L}$ and .012 in Ganga Kasi others sample FRC found below detection limit (Figure 14).

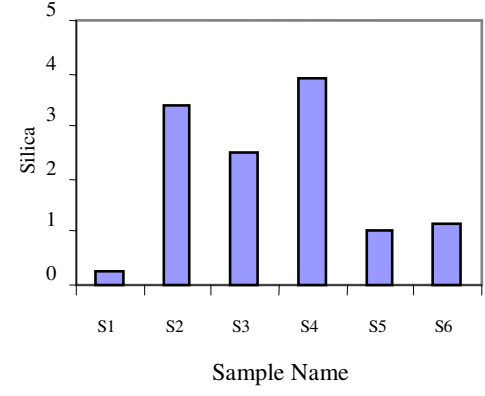

Figure 13. Silica in various sample

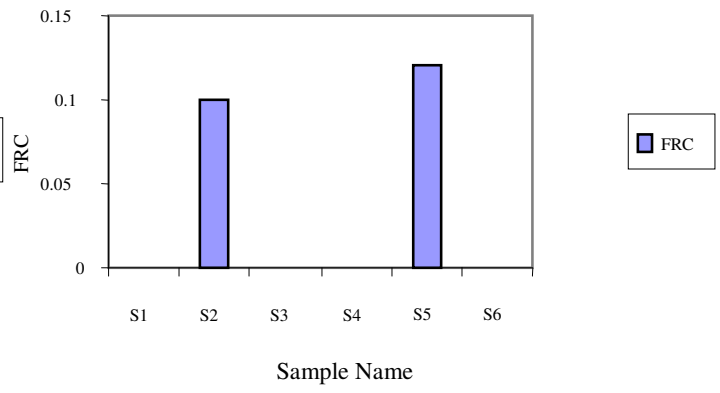

Figure 14. FRC in various sample 


\section{Hydrazine}

In the present study hydrazine concentration varies from below detection limit to 0.018 $\mathrm{mg} / \mathrm{L}$. The hydrazine found below detection limit in Krishna Vijaywada and Mahanadi Katak, other value 0.001, 0.0020 and 0.005 in Cauvery river Tiruchirapalli Ganga Kasi, Hoogali Kolkata and .0180 in Ganga Kasi respectively (Figure 15).

Zinc

Zinc found in some natural waters, most frequently in areas where it is mined. It is not considered for good health when occurs in water at high concentrations. It imparts an undesirable taste to drinking water. For this reason, the secondary maximum contaminant level (SMCL) of zinc in water was set $5.0 \mathrm{mg} / \mathrm{L}$. In the present study the zinc is found to have normal SMCL in all samples as shown Table 2 . The value of zinc is found ranging from $0.05 \mathrm{mg} / \mathrm{L}$ to $3.81 \mathrm{mg} / \mathrm{L}$ in Krishana Vijaywada (Figure 16).

Table 2. Heavy metal analysis

\begin{tabular}{ccccccccc}
\hline S. No & Parameters & $\begin{array}{c}\text { Specifications } \\
\text { as per I.S. }\end{array}$ & S1 & S2 & S3 & S4 & S5 & S6 \\
\hline 1 & Iron & $0.3-1 \mathrm{mg} / \mathrm{L}$ & 0.258 & 0.29 & 0.28 & 0.3 & 0.13 & 0.15 \\
2 & Zinc & $5-15 \mathrm{mg} / \mathrm{L}$ & 3.81 & 0.89 & 2.3 & 0.19 & 0.26 & 0.05 \\
3 & Nickel & $0.02 \mathrm{mg} / \mathrm{L}$ & 0.081 & 0.065 & ND & 0.110 & 0.011 & 0.020 \\
4 & Chromium & $0.05 \mathrm{mg} / \mathrm{L}$ max. & 0.05 & 0.15 & 0.08 & 0.63 & ND & 0.01 \\
\hline
\end{tabular}

Sample code: $S 1=$ Krishna Vijaywada, $S 2=$ Gomati Lucknow, $S 3=$ Hoogali Kolkata, $S 4=$ Ganga Kasi, $S 5=$ Maha Nadi Katak, S6=Cauveri river Tiruchirapalli, $N D=$ Not detected

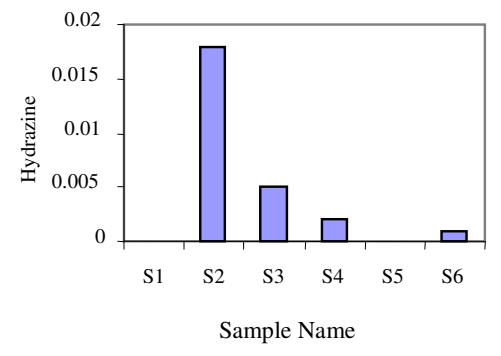

Figure 15. Hydrazine in various sample

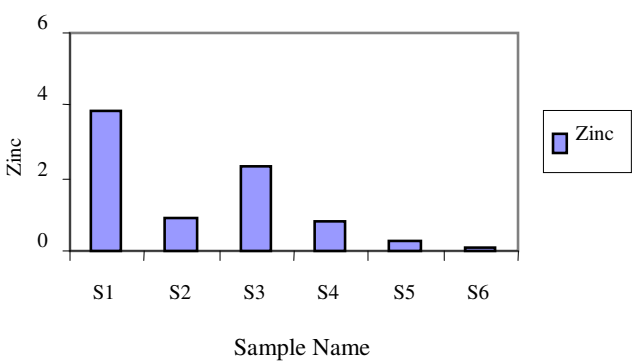

Figure 16. Zinc in various sample

\section{Chromium}

The concentration of chromium in the river water was quit low and fluctuated very widely. Chromium is a specific pollutant providing evidence of industrial pollution like dyeing or paint operations. The Cr present in high range $0.63 \mathrm{mg} / \mathrm{L}$ in Ganga Kasi and water, while in other samples the $\mathrm{Cr}$ level is high varying from below detection limit to $0.45 \mathrm{mg} / \mathrm{L}$ in Gomati Lucknow due to Industrial complex having a number of textiles dyeing and ceramic industries. Cr uptake in some aquatic plants has been reported to range from 1 to $21 \mathrm{mg} / \mathrm{L} \mathrm{in}$ contaminated waters ${ }^{19-20}$ others value of chromium level shown in Table 2 and Figure 17.

\section{Iron}

Concentration of Fe ranged from 0.12 to $0.256 \mathrm{mg} / \mathrm{L}$ in the rivers water. The values of $\mathrm{Fe}$ are much higher than that of the other heavy metals. The world average of Fe in uncontaminated soils is much higher ${ }^{21}$ than other metals i.e. $46 \mathrm{mg} / \mathrm{L}$ indicating geological occurrence of this metal in quite high concentrations. It is done utilization of Fe occurs in large quantities in various domestic and industrial activities, yet the enrichment value is less than 1 indicating 
insignificant effect of anthropogenic flux of this element into water. Similar observations of insignificant $\mathrm{Fe}$ enrichment have also been reported. Iron is an essential element for plants. In the present study all the water samples have the less amount of Fe than I.S parameter as shown in Figure 18.

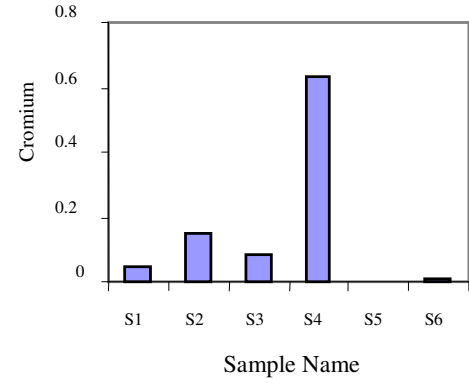

Figure 17. Cromium in various sample

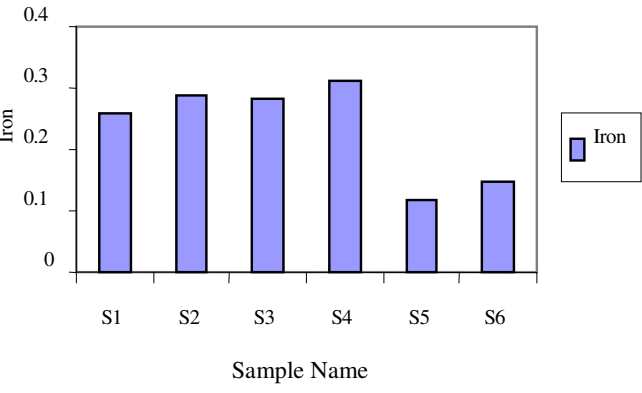

Figure 18. Iron in various sample

\section{Nickel}

In the present work the nickel concentrations in water ranged from $0.011 \mathrm{mg} / \mathrm{L}$ in Maha Nadi Katak and $0.11 \mathrm{mg} / \mathrm{L}$ Ganga in Kasi, the effluents of electroplating industries and cycle industry could be potential source of $\mathrm{Ni}$ in the $\operatorname{river}^{22}$. The concentration of $\mathrm{Ni}$ in different water sample is given in Table 2 and Figure 19.

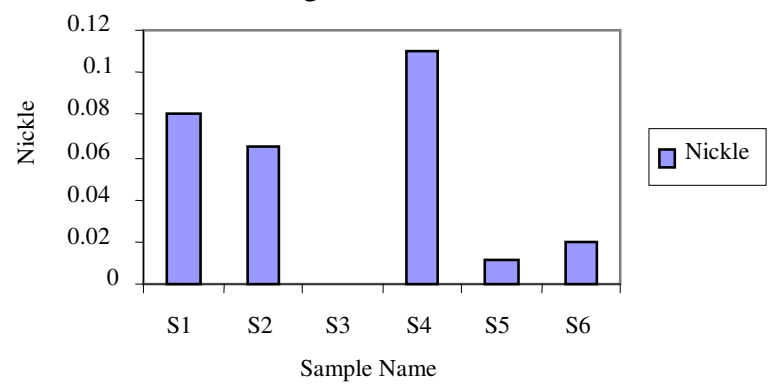

\section{Conclusion}

Figure 19. Nickle in various samples

River water pollution is not only an aesthetic problem, but a serious economic and public health problem as well. Periodical monitoring of the water quality is thus required to assess the condition of surface water. This will be helpful in saving the river from further degradation. The result obtained in this investigation provides the characteristics of water most of all parameters are within the permissible limits except chromium. The chromium concentration is found more than IS specification in river water samples S1, S2 and S3. In S4 sample chromium concentration found at border limit. In four river water sample down stream of dying, paint \& lather industries which need immediate attention for Cr removal from the waste water prior to discharge.

\section{References}

1. Datar M O and Vashistha R P, Indian J Environ Protect., 1992, 12, 577-580.

2. Das N K and Sinha R K, Environ Ecol., 1993, 11(4), 829-832.

3. EPA U S, Primer for Municipal Wastewater Treatment Systems, Document No. EPA 832-R-04-001, 2004. 
4. Goel P K, Water Pollution, Cause, Effects and Control Second Revised Edition, New Age International Publishers, 2006, 2.

5. http://finance.yahoo.com/columnist/article/trenddesk/3748

6. United States Geological Survey (USGS), Denver, Colorado, Ground Water and Surface Water: A Single Resource, USGS Circular 1139, 1998.

7 Kausik A, Ankur Kansal, Santosh, Meena, Shiv Kumari and Kaushik C P, J Hazrd Mater., 2009, 164, 265-270.

8. Dhrendra Mohan Joshi, Alok Kumar and Namita Agrawal, Rasayan J Chem., 2009, 2(2), 285-292.

9. Surindra Suthar, Jitendra Sharma, Mayuri Chabukdhara, Arvind K Neema, Environ Monit Assess., 2010, 165,103-112.

10. Tiwary R K, Rajak G P, Abhishek and Mundal M R, J Environ Sci Eng., 2005, 47(4), 326-335.

11. CPCB Water Quality Status of Yamuna River.Assessment and Development of River Basin Series: ADSORBS/32/1999-2000, Central Pollution Control Board, New Delhi, India, 2000.

12. Trivedy R K, Goel P K and Trisal C L, Practical Methods in Ecology and Environmental Science, Environ Media Publication, Karad, India, 1998.

13. American Public Health Association (APHA), Study Standard Methods for the Examination of Water and Wastewater 20 Edition. Washington D C, 1998.

14. Ahmed S S, Mazumder Q H, Jahan C S, Ahmed M and Islam S, J Geol Soc India, 2002, 60, 411-418.

15. Abida Begum, HariKrishna S and Irfanulla Khan, Rasayan J Chem., 2008, 1(4), 774-781

16. Abida Begum, Harikrishna S, Irfanulla Khan, Ramaiah M, Veena K and Vinutha K, Rasayan J Chem., 2008, 1(3), 596-601.

17. Abida Begum, Harikrishna S, Irfanulla Khan, Ramaiah M, Veena K and Vinutha K, Rasayan J Chem., 2008, 1(3), 572-580.

18. Pitchaiah P S, Ground Water, Scientific Publ Jodhpur, Rajasthan, 1995, 304.

19. Martin J H and Knaeur G A, The Elemental Composition of Phytoplankton, Geochem Cosmochem Acta, 1973, 37, 1639.

20. Mehra A, Farago M E and Banerjee D K, Environ Monit Assess., 2000, 60(1), 25-45.

21. Wedepohl K H, The Composition of the Upper Earth's Crust and the Natural Cycles of Selected Metals in Natural Raw Materials, Natural Resources, in: E. Merian (Ed.), Metals and their Compounds in Environment: Occurrence, Analysis and Biological Relevance, VCH, New York, 1991, 3-17.

22. Samasekhar R K, Ramaswamy R K and Arekal D G, Int J Environ Stud., 1982, 20, 63-65. 


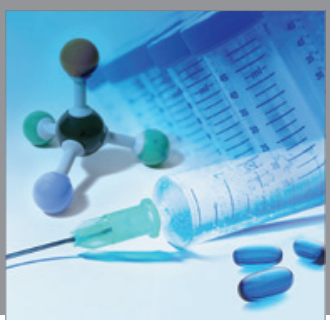

International Journal of

Medicinal Chemistry

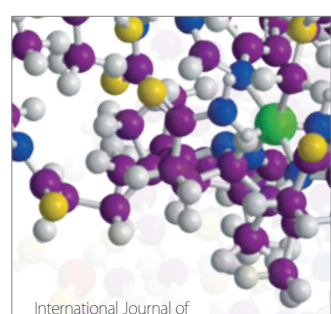

Carbohydrate Chemistry

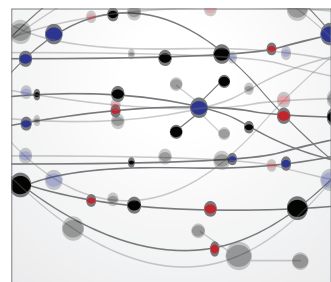

The Scientific World Journal
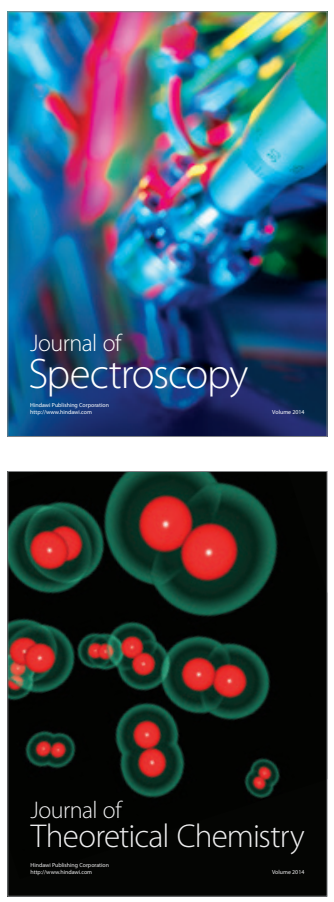
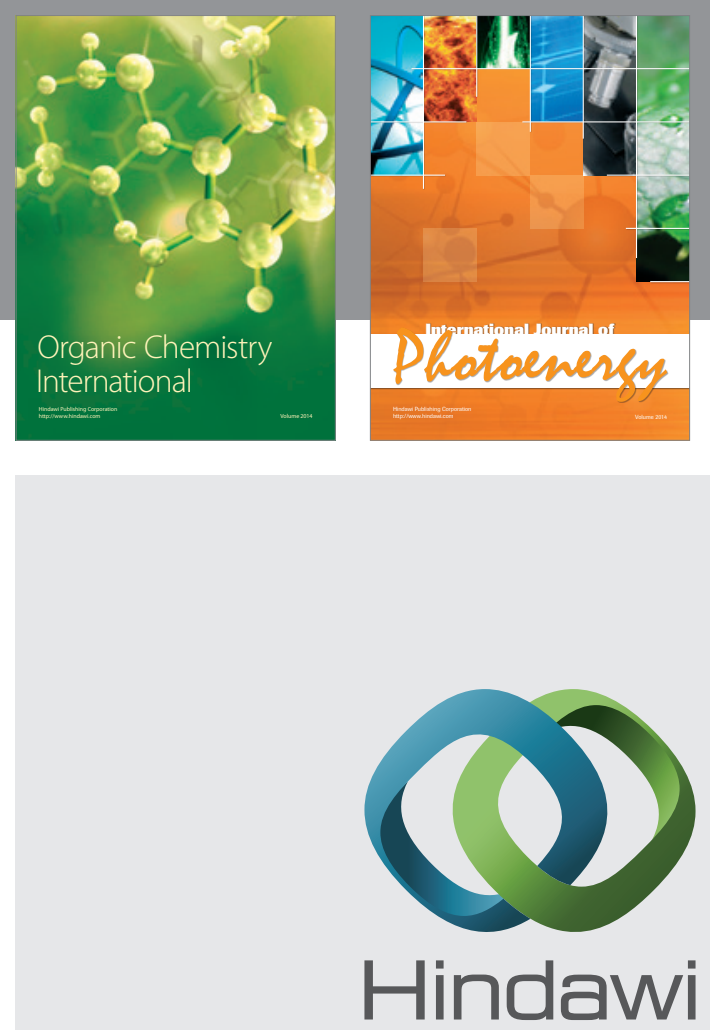

Submit your manuscripts at

http://www.hindawi.com
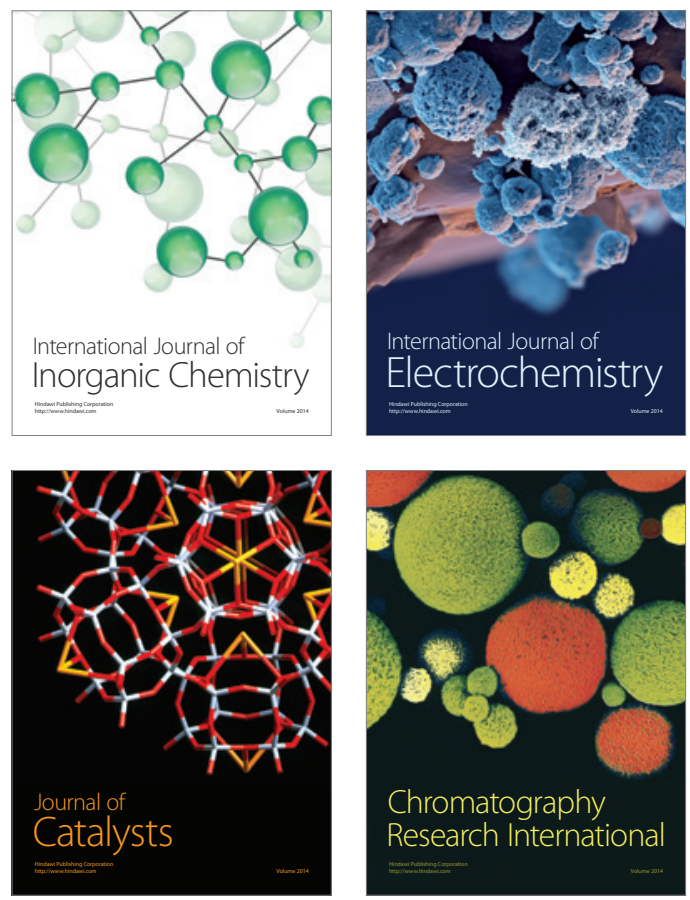
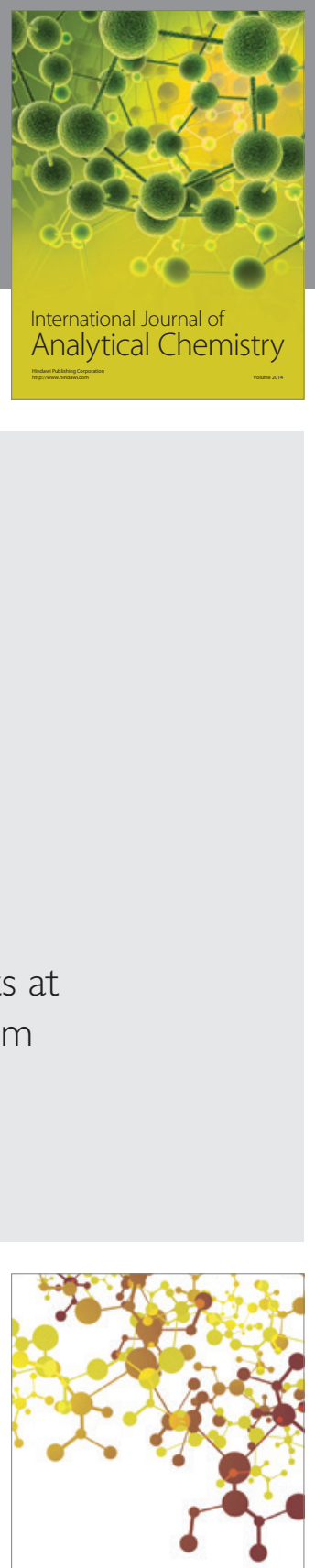

Journal of

Applied Chemistry
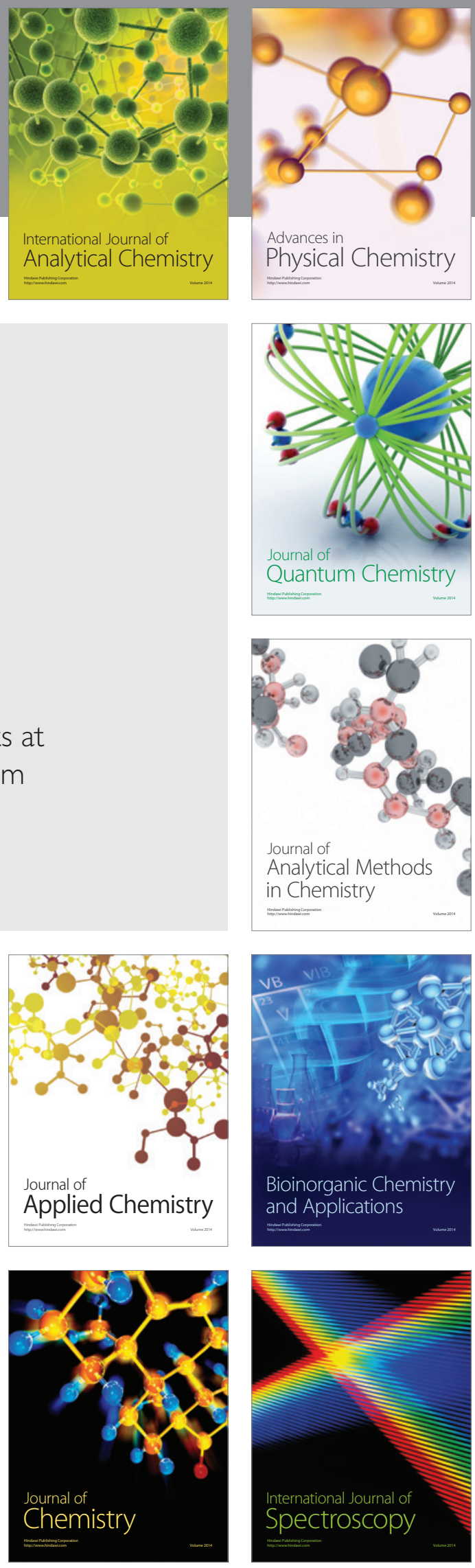